\title{
Shikimate Accumulation, Glyphosate Absorption and TRANSLOCATION IN HORSEWEed BIOTYPES ${ }^{1}$
}

\author{
Acúmulo de Chiquimato, Absorção e Translocação do Glyphosate em Biótipos de Buva
}

\author{
CARDINALI, V.C.B. ${ }^{2}$, DIAS, A.C.R. ${ }^{3}$, MUELLER, T.C. ${ }^{4}$, ABERCROMBIE, L..${ }^{4}$, STEWART JR. C.N. ${ }^{4}$, \\ TORNISIELO, V.L. ${ }^{2}$, and CHRISTOFFOLETI, P.J. ${ }^{2}$
}

\begin{abstract}
In Brazil, few research works on mechanisms of weed resistance to glyphosate have been conducted so far. Therefore, this research aimed to study analytical procedures determining the relation between the concentration of plant shikimate after glyphosate application and the plant resistance to this herbicide; and evaluate the glyphosate absorption and translocation into two resistant (R) and susceptible (S) horseweed biotypes to glyphosate. Horseweed plants with nine true leaves received glyphosate (720 g a.e. ha $\left.{ }^{-1}\right)$, and 2, 3, 4, 7 and 10 days after application (DAA) the concentration of shikimic acid was measured by HPLC. In another experiment, plants were treated with radiolabeled glyphosate $\left({ }^{14} \mathrm{C}\right)$ (1.456 $\mathrm{MBq} \mathrm{mmol}^{-1}$ specific activity) and radioactivity was measured 4, 8, 24, 48 and 72 hours after treatment (HAT) by liquid scintillation spectrometry. The shikimate concentration in plants increased 16,351.14 and 7,892.25 $\mathrm{mg} \mathrm{kg}^{-1}$ of dry weight, for R and S plants respectively, at seven DAA. Therefore, the procedure for quantification of shikimic acid was suitable for $\mathrm{R}$ and $\mathrm{S}$ plants differentiation to glyphosate, indicating that the R population is actually resistant to glyphosate. On average, $98 \%$ of glyphosate applied was absorbed by the studied biotypes, at 72 HAT. Around $68 \%$ of the absorbed radioactivity remained on the biotypes leaves treated, the $\mathrm{S}$ biotype showing the highest translocation. Therefore, the $\mathrm{R}$ biotype resistance mechanism studied is associated to the differential translocation.
\end{abstract}

Keywords: Conyza bonariensis, High Performance Liquid Chromatography, EPSPS, selection, radioactivity.

RESUMO - No Brasil, poucos trabalhos de pesquisas com mecanismos de resistência de plantas daninhas ao glyphosate foram conduzidos até o momento. Assim, o objetivo desta pesquisa foi estudar procedimentos analiticos para determinar a relação da concentração de chiquimato na planta após aplicação de glyphosate e a resistência da planta a este herbicida, bem como avaliar a absorção e translocação do herbicida glyphosate em dois biótipos de buva, resistente (R) e suscetivel (S) ao glyphosate. Plantas de buva com nove folhas definitivas receberam glyphosate (720 g e.a. ha-1), e 2, 3, 4, 7 e 10 dias após a aplicação (DAA) foi medida a concentração de ácido chiquímico da parte aérea, através de HPLC. Em outro experimento, as plantas foram tratadas com glyphosate radiomarcado $\left({ }^{14} \mathrm{C}\right)$ (atividade específica de 1,456 $\mathrm{MBq} \mathrm{mmol}^{-1}$ ), e a radioatividade foi determinada 4, 8, 24, 48 e 72 horas após o tratamento (HAT), por espectrometria de cintilação liquida. A concentração de chiquimato aumentou (16.351,14 e 7.892,25 $\mathrm{mg} \mathrm{kg}^{-1}$ de matéria seca nas plantas $R$ e $S$, respectivamente) aos $7 \mathrm{DAA}$. Portanto, o procedimento de quantificação do ácido chiquímico foi adequado para diferenciação das plantas $R$ e $S$ ao glyphosate, indicando que a população $R$ estudada é resistente ao glyphosate. Em média, 98\% do glyphosate aplicado foi absorvido pelos biótipos estudados 72 HAT. Cerca de 68\% da radioatividade absorvida permaneceu nas folhas tratadas dos biótipos, sendo que o biótipo $S$ foi o que mais translocou. Assim, o mecanismo de resistência no biótipo $R$ estudado está relacionado com a translocação diferencial.

Palavras-chave: Conyza bonariensis, cromatografia líquida de alta eficiência, EPSPS, seleção, radioatividade.

Recebido para publicação em 31.3.2014 e aprovado em 23.9.2014.

2 Universidade de São Paulo, Piracicaba-SP, Brazil, <vanessacardinali@yahoo.com,br>, <pjchrist@usp.br>; ${ }^{3}$ Universidade do Estado de Mato Grosso, Alta Floresta-MT, Brazil; ${ }^{4}$ University of Tennessee Plant Science Knoxville-TN.

Planta Daninha, Viçosa-MG, v. 33, n. 1, p. 109-118, 2015 


\section{INTRODUCTION}

Conyza bonariensis, popularly known as horseweed, is an annual cycle plant, originating in the United States (Stubbendieck et al., 1994), which spreads by wind, being able to settle under different environmental conditions (Bhowwik \& Bekech, 1993; Vidal et al., 2007). Initially these plants were a problem in abandoned areas, however in the last three decades the reduction of conventional planting practices and the adoption of soil conservation systems, specifically the direct seeding system, contributed to these species infestation in agricultural areas (Buhler \& Owen 1997; Weaver et al., 2001). Among the herbicides used to control C. bonariensis, is glyphosate.

The glyphosate herbicide, derived from amino acids, acts on the shikimic acid route, competing for the same action site of enolpyruvylshikimate-phosphate synthase enzyme (EPSPS), thereby promoting the 5enolpyruvylshikimate-3-phosphate synthase reduction, a precursor of aromatic amino acids synthesis and phenolic compounds (Monquero et al., 2004; Moreira \& Christoffoleti, 2008).

With the increased use of glyphosate, primarily as a result of GM crops, the selection of herbicide resistant weeds is becoming more frequent (Christoffoleti et al., 2008). The first report of Conyza bonariensis resistance to glyphosate occurred in 2003, and currently resistance cases have been proven in South Africa, Spain, Brazil, Colombia and the United States (Heap, 2008). Vargas et al. (2007) observed a low response of a $C$. bonariensis biotype, considered resistant to glyphosate when submitted to high doses of the herbicide. The same was observed by Moreira et al. (2007) in a citrus orchard in the State of São Paulo.

Several researches have been conducted aiming to elucidate the weeds' resistance mechanisms to glyphosate, nevertheless they are still unclear (Moreira \& Christoffoleti, 2008). As other weeds resistant to glyphosate, the $C$. bonariensis hasn't its resistance mechanism elucidated so far. Absorption, translocation and differential metabolism are possible mechanisms involved in this species resistance.
There are several methods for detecting weed resistance to herbicides (Beckie et al., 2000). Field or greenhouse tests are the most common ones and deliver reliable results. However, one of the negative aspects of these tests is that they require a long time to obtain the final result. The shikimic acid accumulation in plant tissues treated with glyphosate may be an alternative for rapid detection of populations resistant to this herbicide. EPSPS competitive inhibition by glyphosate results in the shikimate accumulation in the affected tissues (Bresnahan et al., 2003).

This study aimed to evaluate absorption, translocation and the development of an analytical procedure to quantitatively determine the shikimate in $C$. bonariensis resistant and susceptible plants after glyphosate application and confirm this herbicide resistance of that species suspected population.

\section{MATERIAL AND METHODS}

\section{Experiment I: Shikimate accumulation in horseweed susceptible and resistant biotypes}

The first experiment was conducted in the Plant Science Department greenhouse, University of Tennessee, located in KnoxvilleTN - USA (3557'16" N, 8355'46" W and $276 \mathrm{~m}$ altitude), between February and March 2008. Two horseweed populations (Conyza bonariensis) were used, one with suspected resistance arising from the municipality of Matão-SP (Cambuhy farm), with approximately 15 years of growing citrus with glyphosate annual applications, and another one possibly susceptible, collected from an area with no glyphosate application history, in PiracicabaSP. Seeds of the two biotypes were collected from grown plants at physiological maturity stage, being further on sown in pots of $15 \mathrm{~cm}$ diameter x $12 \mathrm{~cm}$ high, containing Plantmax type commercial substrate and vermiculite in a 2:1 ratio, duly fertilized with $200 \mathrm{mg}$ of $\mathrm{N}$, $\mathrm{P}_{2} \mathrm{O}_{5}$ e $\mathrm{K}_{2} \mathrm{O}$. The pots were identified, irrigated and then seeds were deposited on the surface and covered with a thin layer of substrate. Thirty days after germination, 
plants containing three true leaves were transferred individually into pots of $200 \mathrm{~mL}$ capacity.

When plants had nine sheets and reached an average height of $15 \mathrm{~cm}$, glyphosate application was done equivalent to 720 g a.e. ha- ${ }^{-1}$ dose (minimum dose to control horseweed). Herbicide application was made on February 11, 2008 between 9am and 9.30am. At this time, average meteorological parameters were: $75 \%$ relative humidity $(\mathrm{RH})$, $25.4{ }^{\circ} \mathrm{C}$ temperature $(\mathrm{T})$, sky with no clouds and winds of $1.5 \mathrm{~km} \mathrm{~h}^{-1}$. Treatments consisted of two biotypes, identified as susceptible (S) and resistant (R), five collection times $(2,3,4$, 7 and 10 days after application - DAA) and four replications. Collections of the plant aerial parts (leaves + stem) were made at 2, 3, 4, 7 and 10 days after the herbicide application (DAA), being then kept in a freezer at $-20^{\circ} \mathrm{C}$ until analyzes processing.

The shikimic acid extraction procedure used was similar to the one employed by Mueller et al. (2003). In this process, plants (leaves + stem) were macerated and homogenized with fluid nitrogen aid $\left(\mathrm{N}_{2}\right)$. Then, a mass between 0.5 and $1.0 \mathrm{~g}$ of leaf tissue from each sample was weighed and packed in a glass bottle of $20 \mathrm{~mL}$ capacity; afterwards $15 \mathrm{~mL}$ of $\mathrm{HCl} 1.0 \mathrm{~mol} \mathrm{~L}^{-1}$ solution was added. Subsequently, the pots were shaken on an orbital table for 24 hours at $1500 \mathrm{rpm}$. After shaking, the extracts were filtered with Whatman $\mathrm{n}^{\circ} 1$ filter and collected in a graduated cylinder, until they reached a volume of $5.0 \mathrm{~mL}$. Then $250 \mu \mathrm{L}$ of $\mathrm{NaOH}$ saturated and $2.5 \mathrm{~mL}$ of acetonitrile were added to the pots. The extract was strained by a $0.45 \mu \mathrm{m}$ nylon filter, coupled to a syringe and added to chromatography pots of $2.0 \mathrm{~mL}$.

The plant shikimic acid quantification (Cromartie \& Polge, 2000) was done using a High Performance Liquid Chromatography technique (HPLC) with Agilent 1100 chromatograph (Wilmington, DE), equipped with "Chemstation" software, a self-injection and a diode chain detector (DCD). The equipment was operated with Phenomenex Luna $\mathrm{NH}_{2} 100 \mathrm{~A}(250 \mathrm{~mm} \times 4.6 \mathrm{~mm} \times 5.0 \mu \mathrm{m})$ and the peaks monitoring was done in wave length of $215 \mathrm{~nm}$. The mobile phase consisted of an isocratic system (acidified water $1 \% \mathrm{H}_{2} \mathrm{PO}_{4}$ : acetonitrile, $15: 85 \mathrm{v} / \mathrm{v}$ ) with $1.0 \mathrm{~mL} \mathrm{m^{-1 }}$ flow and sample injection volume equal to $10 \mu \mathrm{L}$. The running time was 20 min and the shikimic acid retention time, $7.4 \mathrm{~min}$. The shikimic acid quantification was also done before the herbicide application in all studied populations (time 0).

All data were subjected to the F test application in the variance analysis, and then adjusted to curves using linear regression, to compare the acid shikimic amounts of the analyzed populations.

\section{Experiment II: Foliar absorption and translocation of glyphosate herbicide in horseweed resistant and susceptible biotypes}

In this experiment, plants grew in a greenhouse located at the Centro de Energia Nuclear na Agricultura (CENA/USP), Piracicaba-SP (22 $42^{\prime} 30^{\prime \prime} \mathrm{S}, 4^{\circ} 38^{\prime} 00^{\prime}$ 'W and $546 \mathrm{~m}$ altitude). Laboratory analyzes were performed at the Ecotoxicology Laboratory CENA/USP and at Radiochemistry Laboratory of BIOAGRI Laboratórios Ltda., Piracicaba-SP. Two C. bonariensis populations were used: one glyphosate resistant (R) originating from seeds collected in an area of herbicide application history of at least 10 consecutive years in Cruz Alta, Rio Grande do Sul state - these seeds were previously tested for dose-response curve, proving that it is a resistant population; and one glyphosate susceptible (S), whose seeds were collected in Piracicaba-SP, in an area with no glyphosate application history.

Seeds were collected from full maturity plants and identified according to location and date of collection. For identification, morphological features described in Kissmann \& Groth (1997) were used. Subsequently, seeds were sown in plastic trays containing a mixture of commercial substrate and vermiculite at a 1:1 ratio.

Ten days approximately after sowing, most of the seeds had emerged, and when plants showed two true leaves of phenological stage, they were transferred individually to pots with $500 \mathrm{~mL}$ capacity, duly completed with commercial substrate and fertilized with a 
commercial formulation of $14-14-14$ (N-P-K), at a $2.0 \mathrm{~g}$ dose per pot.

The experimental design was a completely randomized $5 \times 2$ factorial scheme with four replications. One glyphosate sub dose equivalent to $7.2 \times 10^{-3}$ g e.a. ha-1 was used, with five assessment times and two C. bonariensis biotypes. When plants had 9-10 true leaves, a selection of the most homogeneous plants was done, then taken to the Ecotoxicology laboratory (CENA/USP), where the herbicide application on the leaves took place.

The herbicide solution (working solution) was prepared diluting carbon-14 labeled glyphosate (specific activity $1.456 \mathrm{MBq} \mathrm{mmol}^{-1}$ ), and commercial glyphosate, obtaining a final concentration equivalent to $7.2 \times 10^{-3} \mathrm{~g}$ e.a. ha- $\mathrm{ha}^{-1}$ with $0.06 \mathrm{MBq} \mu \mathrm{L}^{-1}$ radioactivity.

The herbicide application was made using a micro-applicator (Hamilton PB6000 Dispenser Hamilton Co. EUA), on the adaxial three leaf stage in the plant's middle part, in the form of four drops of $1.0 \mu \mathrm{L}$ each, totaling 12 drops per plant, with a $0.67 \mathrm{MBq}$ radioactivity per plant.

The absorption and translocation were evaluated at 4, 8, 24, 48 and 72 hours after herbicide treatment (HAT). In each period, plants were removed from pots and divided into roots, shoots and treated foliage, aiming to quantify the radioactivity in each one.

The treated leaves were removed from the plant and washed with $80 \%$ methanol, to determine the herbicide fraction unabsorbed by the sheet. The liquid resulting from washing the leaves was added to scintillation pots, containing a scintillation solution; then, the radioactivity contained in each pot was determined by a liquid scintillation spectrometry (ECL) (Packard 1900 TR). Roots tissues, shoots and treated leafs analyses were taken through the samples' combustion by a biological oxidizer (OX 600 Harvey Instruments). Afterwards, the radioactivity by ECL was quantified.

The herbicide absorption by the sheet was determined as the radioactivity percentage contained within the plant (aerial parts, roots and treated leaves) compared to the total radioactivity recovered (rinsing liquid + sheets radioactivity within the plant). In the translocation calculation the radioactivity in each part of the plant was evaluated, compared to total radioactivity recovered.

Results obtained were subjected to the variance analysis and Tukey's multiple comparison tests ( $5 \%$ probability).

Qualitative translocation studies were performed by autoradiography. The plants used were treated as mentioned above, however in each collection period they were washed, dried and pressed and subsequently passed into a Radio Scanner (Packard-Cyclone).

\section{RESULTS AND DISCUSSION}

\section{Experiment I: Shikimate accumulation in horseweed susceptible and resistant biotypes}

The evaluations average results of the shikimate populations' concentration that were sprayed with glyphosate, were adjusted to a simple linear equation, with good data adjustment, as can be seen in Figure 1. In Table 1 the parameters setting values of the regression equation $\mathrm{a}, \mathrm{b}, \mathrm{F}$ and respective significance are shown, beyond $\mathrm{R}^{2}$ correlation coefficient. Statistical significance could be observed by the $\mathrm{F}$ test at 5\% probability for the two equation parameters (data not shown); the $\mathrm{R}^{2}$ value close to 0.97 for both equations also

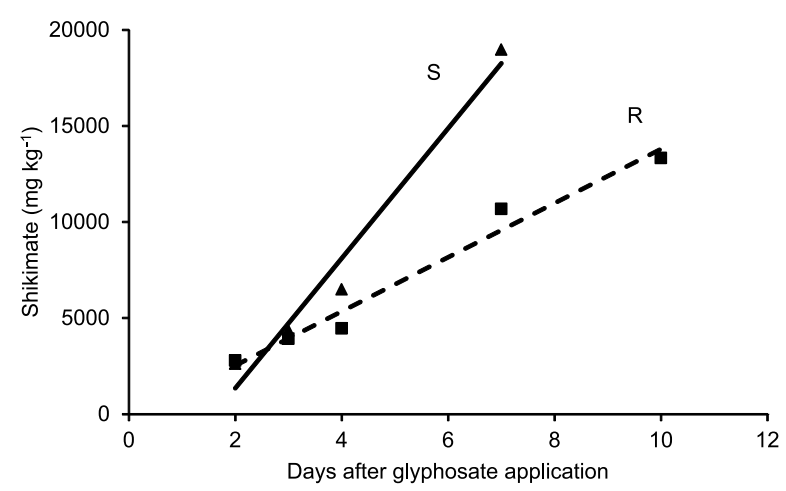

Figure 1 - Shikimate concentration in resistant $(\mathrm{R})$ and susceptible (S) plants. Continuous and dashed lines represent continuous values adjusted by the linear regression equation for $\mathrm{R}$ and $\mathrm{S}$ plants, respectively, as well as triangular and square symbols represent the average original values obtained in $\mathrm{R}$ and $\mathrm{S}$ plants experiment, respectively. 
Table 1 - Parameters of the linear equation $\mathrm{y}=\mathrm{a}+\mathrm{b} . \mathrm{x}$ type, used to adjust shikimate accumulation results in $\mathrm{R}$ and $\mathrm{S}$ horseweed plants

\begin{tabular}{|l|c|c|c|c|c|}
\hline & $\mathrm{a}$ & $\mathrm{b}$ & $\mathrm{F}$ regression & $\mathrm{P}>\mathrm{F}$ & $\mathrm{R}^{2}$ \\
\hline Susceptible Plants & -5411.22 & 3381.09 & 65.09 & 0.015 & 0.970 \\
\hline Resistant Plants & 3381.09 & 1408.88 & 110.54 & 0.0018 & 0.973 \\
\hline
\end{tabular}

shows a good data fit in the simple linear model.

The addition of the shikimate accumulated value in $\mathrm{S}$ plants from 2 DAA $\left(2,629.00 \mathrm{mg}\right.$ of shikimate $\mathrm{kg}^{-1}$ of dry matter $)$ per $18,980.14 \mathrm{mg}$ of shikimate $\mathrm{kg}^{-1}$ of dry matter, at 7 DAA in horseweed plants, indicates the herbicide action inhibiting EPSPS, resulting thereby in the shikimate accumulation. Shikimate accumulation in $\mathrm{R}$ plant tissues was also observed, however at a much lower concentration, i.e., 2,791.60 mg of shikimate $\mathrm{kg}^{-1}$ of dry matter at 2 DAA per $10,683.85 \mathrm{mg}$ of shikimate $\mathrm{kg}^{-1}$ of dry matter, indicating that $\mathrm{R}$ plants have lower inhibition level of EPSPS and can consequently be considered resistant to this herbicide.

Similar results were obtained by Mueller et al. (2003), who observed higher shikimate accumulation than $1,000 \mu \mathrm{g} \mathrm{g}^{-1}$ in $\mathrm{R}$ plant tissues; however, there were significant differences in the shikimate accumulation patterns between $\mathrm{R}$ and $\mathrm{S}$ horseweed biotypes.

Table 2 shows shikimate amount in plants without the herbicide application. The differences observed should not be attributed to phenotypic differences among biotypes, for the values dimensions found are insignificant when compared to the plants data, after the herbicide application. In the research conducted by Mueller et al. (2003), the shikimate concentration in non treated plants with glyphosate was less than $100 \mu \mathrm{g} \mathrm{g}^{-1}$, which was significantly lower than those who had been treated with glyphosate at $0.84 \mathrm{~kg}$ e.a. ha ${ }^{-1}$ dose. These results confirm the data obtained in this study that without glyphosate application, there is effectively shikimate accumulation in the plant.

One of the results practical aspects is that the herbicide was applied in intact plants and at the recommended dose of the product
Table 2 - Average shikimate' quantity $\left(\mu \mathrm{g} \mathrm{g}^{-1}\right)$ in R and S plants before treatment with glyphosate

\begin{tabular}{|c|c|}
\hline S Plant & R Plant \\
\hline & $\left(\mu \mathrm{g} \mathrm{g}^{-1}\right)$ \\
\hline 19.01 & 0.00 \\
\hline 15.75 & 0.00 \\
\hline 0.00 & 0.00 \\
\hline 50.77 & 0.00 \\
\hline
\end{tabular}

for the plant (Rodrigues \& Almeida, 2005), i.e., 720 g e.a. ha ${ }^{-1}$. Bioassays, reported in literature, use leaf discs receiving glyphosate concentrations to measure further on the shikimate accumulation. In the corn leaf disc assay, developed to measure the shikimate accumulation, followed by the immersion in a glyphosate solution at concentrations ranging from $25-2500 \mathrm{ppm}$, there was a linear correlation between the shikimate accumulation and the amount of glyphosate applied (Chiang \& Chiang, 2006).

As there was shikimate accumulation in $\mathrm{R}$ plants, however at a lower intensity than in $S$ plants, it can be inferred that the resistance mechanism in these horseweed plants is not due to an overall insensitivity of EPSPS to glyphosate in susceptible plants. If there was a total insensitivity of EPSPS to glyphosate in $\mathrm{R}$ plants, there would be no accumulation of shikimate in them. Among glyphosate resistance mechanisms of weed plants reported in literature, we highlight Feng et al. work (2004), which suggests that resistance is probably due to an altered glyphosate cellular distribution, which prevents the herbicide flow into the phloem and the import inside the plastids, resulting thereby in reduced overall translocation of the herbicide in the plant. Therefore, if this resistance mechanism is the cause of the biotype under study in this research, it explains the shikimate accumulation in resistant plants. 
Other glyphosate resistance mechanisms have been reported in literature, such as gene amplification and EPSPS insensitivity to the herbicide. In characterizing the gene expression levels and EPSPS sensitivity of the ryegrass (Lolium multiflorum) performed by Baerson et al. (2002), evidence of gene amplification or co-segregation of the enzyme specific variant gene were observed in the resistant biotype. In Ng work (2004) however, studying the goosegrass weed (Eleusine indica) it was observed that glyphosate resistance is the result of an incomplete, nuclear and monogenic gene. In this study, the enzyme insensitivity mechanism reported for goosegrass is probably not the same, for in that case there would be no shikimate accumulation in $\mathrm{R}$ plant.

As can be seen in Figure 1 there was no shikimic acid assessment on $\mathrm{S}$ plants aerial parts, but on the R plants only. This occurred because at the time of data collection, the S plants were dead, precluding its analysis. Therefore, it was possible to prove that the studied biotype with suspected resistance was effectively resistant to glyphosate, for the recommended dose of the herbicide was applied.

In this work, the isolation procedure and the shikimic acid quantification on plants treated with glyphosate is suitable for differentiation of resistant plants to glyphosate susceptible horseweed plants (Conyza bonariensis). The population used in this study, suspected of resistance, was confirmed as glyphosate resistant. Although speculative through indirect evidences, the studied horseweed biotype resistance mechanism is not related to the EPSPS insensitivity to glyphosate.

\section{Experiment II: Glyphosate herbicide foliar absorption and translocation in horseweed resistant and susceptible biotypes}

The variance analysis results showed no statistically significant differences between the $\mathrm{R}$ and $\mathrm{S}$ biotypes regarding the glyphosate absorption by leaves that receive the droplets of the radio labeled herbicide solution. The glyphosate percentage up to 72 HAT absorbed, in both horseweed biotypes, was approximately $98 \%$ of the total radioactivity applied, with no difference between $\mathrm{R}$ and $\mathrm{S}$ plants (Figure 2). Koger \& Reddy (2005) also observed no differences in the glyphosate amount absorbed by Conyza canadensis $\mathrm{R}$ and $\mathrm{S}$ biotypes.

After 72 hours, around $69 \%$ of total ${ }^{14} \mathrm{C}$ glyphosate absorbed, remained on treated leaves in the resistant and susceptible biotypes (Figure 3). Feng et al. (2004), Koger \& Reddy (2005) and Dinelli et al. (2006) studied Conyza canadensis resistant and susceptible biotypes to glyphosate and found high retention of the herbicide on the treated leaf of the resistant biotype.

Regarding the amount of translocated herbicide, differences between $\mathrm{R}$ and $\mathrm{S}$ biotypes were observed. After 72 hours, $36.1 \%$ of total herbicide absorbed was translocated to the susceptible biotype roots,

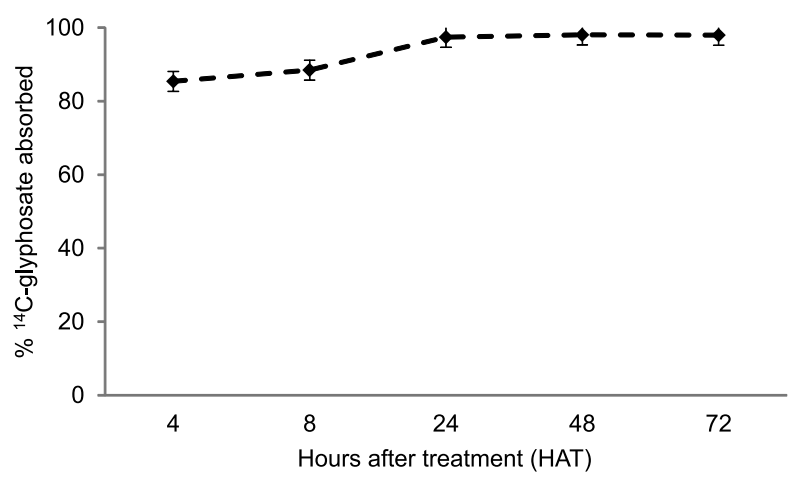

Figure 2 - Average absorption of ${ }^{14} \mathrm{C}$-glyphosate in Conyza bonariensis resistant $(\mathrm{R})$ and susceptible $(\mathrm{S})$ biotypes.

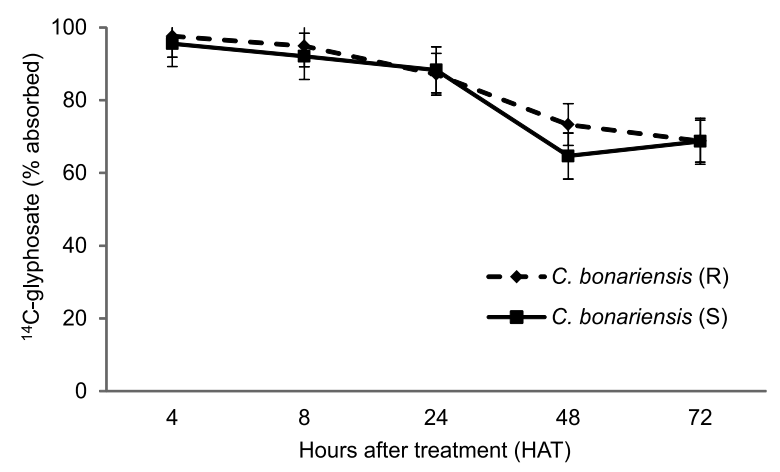

Figure $3-{ }^{14} \mathrm{C}$-glyphosate remaining in treated leaves of Conyza bonariensis resistant $(\mathrm{R})$ and susceptible (S) biotypes. 
while the resistant biotype translocation to the roots was $21.6 \%$ (Tables 3 and 4 ). The same result was observed by Feng et al. (2004) and later on by Koger \& Reddy (2005) in C. canadensis susceptible and resistant biotypes. Whereas glyphosate moves both through phloem as xylem (Peterson, 1989) and that xylem transport is approximately 20-50 times faster than in the phloem (Kleier \& Hsu, 1996), it can be inferred that the molecule preferential transport would be toward the leaves (Dinelli et al., 2006).

Ferreira et al. (2008) studied the glyphosate' translocation of $C$. bonariensis resistant and susceptible biotypes and also noted that the herbicide translocation is much higher in the susceptible biotype, being the plant's root the organ with the highest glyphosate concentration. Around $20 \%$ of the ${ }^{14} \mathrm{C}$-glyphosate applied was found in the susceptible plant's roots 72 hours after application, contrasting with the resistant plants, whose radioactivity was 5\%. These authors also concluded that differential translocation is among the $C$. bonariensis glyphosate resistance mechanisms.

The study of plant autoradiography illustrates this result in both biotypes. By the images (Figure 4), it is observed that most of the radioactivity remained in the treated leaves of both biotypes. In other plant species, differential translocation has been little reported as a weed resistance mechanism to herbicides. However, because glyphosate is a

Table 3 - Radioactivity percentage absorbed in resistant Conyza bonariensis at different collection times

\begin{tabular}{|c|c|c|c|}
\hline \multirow{2}{*}{$\begin{array}{c}\text { Hours after } \\
\text { treatment } \\
(\text { HAT })\end{array}$} & $\begin{array}{c}\text { Treated } \\
\text { leaves }\end{array}$ & Aerial part & Root \\
\cline { 2 - 4 } & \multicolumn{2}{|c|}{$\%$ radioactivity absorbed } \\
\hline 4 & $97.57 \mathrm{a}$ & $0.73 \mathrm{~b}$ & $1.70 \mathrm{~b}$ \\
\hline 8 & $94.87 \mathrm{ab}$ & $1.23 \mathrm{~b}$ & $3.90 \mathrm{~b}$ \\
\hline 24 & $87.10 \mathrm{~b}$ & $3.00 \mathrm{~b}$ & $9.90 \mathrm{~b}$ \\
\hline 48 & $73.27 \mathrm{c}$ & $5.10 \mathrm{~b}$ & $21.60 \mathrm{a}$ \\
\hline 72 & $68.77 \mathrm{c}$ & $9.70 \mathrm{a}$ & $21.60 \mathrm{a}$ \\
\hline $\mathrm{DMS}$ & 8.50 & 4.54 & 9.87 \\
\hline $\mathrm{F}$ & $49.51^{* *}$ & $13.94 * *$ & $20.07 * *$ \\
\hline
\end{tabular}

** F significant value at $1 \%$ probability. Averages followed by the same letters in the column do not differ among them by the Tukey test with $5 \%$ probability. fast and efficient translocation molecule, any herbicide transport reduction to susceptible areas of the plant may cause a large effect regarding plants mortality (Preston $\&$ Wakelin, 2008).

Mechanisms that lead to reduced translocation are still unclear. According to Pedersen et al. (2007), differential translocation in plants could mean some harm degree on the ecological adaptability of resistant plants. Lorraine-Colwill et al. (1999) attributed the translocation reduction in resistant biotypes to a possible change in transport proteins that exist in the chloroplast. Later on, these authors speculated on a possible involvement of the plasma membrane transporters (Lorraine-Colwill et al., 2003). Feng et al. (2004) suggest that resistance is probably due to an altered glyphosate cellular distribution, which prevents the herbicide flow in the phloem and the import into the plastids, resulting thereby in reduced overall translocation of the herbicide in the plant.

Differential translocation, in this work, may be considered one of the mechanisms involved in $C$. bonariensis resistance to glyphosate. The herbicide translocation difference in resistant and susceptible biotypes, used in this study, was quite evident in the presented results, however further studies are needed to prove the existence of other resistance mechanisms in this species.

Table 4 - Radioactivity percentage absorbed in susceptible Conyza bonariensis at different collection times

\begin{tabular}{|c|c|c|c|}
\hline \multirow{2}{*}{$\begin{array}{c}\text { Hours after } \\
\text { treatment } \\
\text { (HAT) }\end{array}$} & $\begin{array}{c}\text { Treated } \\
\text { leaves }\end{array}$ & Aerial part & Root \\
\cline { 2 - 4 } & \multicolumn{2}{|c|}{$\%$ radioactivity absorbed } \\
\hline 4 & $95.57 \mathrm{a}$ & $1.17 \mathrm{c}$ & $3.30 \mathrm{c}$ \\
\hline 8 & $92.03 \mathrm{a}$ & $1.77 \mathrm{bc}$ & $6.20 \mathrm{c}$ \\
\hline 24 & $88.03 \mathrm{ab}$ & $2.07 \mathrm{abc}$ & $9.67 \mathrm{bc}$ \\
\hline 48 & $64.63 \mathrm{c}$ & $4.73 \mathrm{ab}$ & $30.60 \mathrm{a}$ \\
\hline 72 & $68.70 \mathrm{bc}$ & $5.23 \mathrm{a}$ & $36.07 \mathrm{a}$ \\
\hline $\mathrm{DMS}$ & 21.09 & 3.23 & 17.88 \\
\hline $\mathrm{F}$ & $9.82^{* *}$ & $7.13^{* *}$ & $10.32^{* *}$ \\
\hline
\end{tabular}

** F significant value at $1 \%$ probability. Averages followed by the same letters in the column do not differ among them by the Tukey test with $5 \%$ probability.

Planta Daninha, Viçosa-MG, v. 33, n. 1, p. 109-118, 2015 

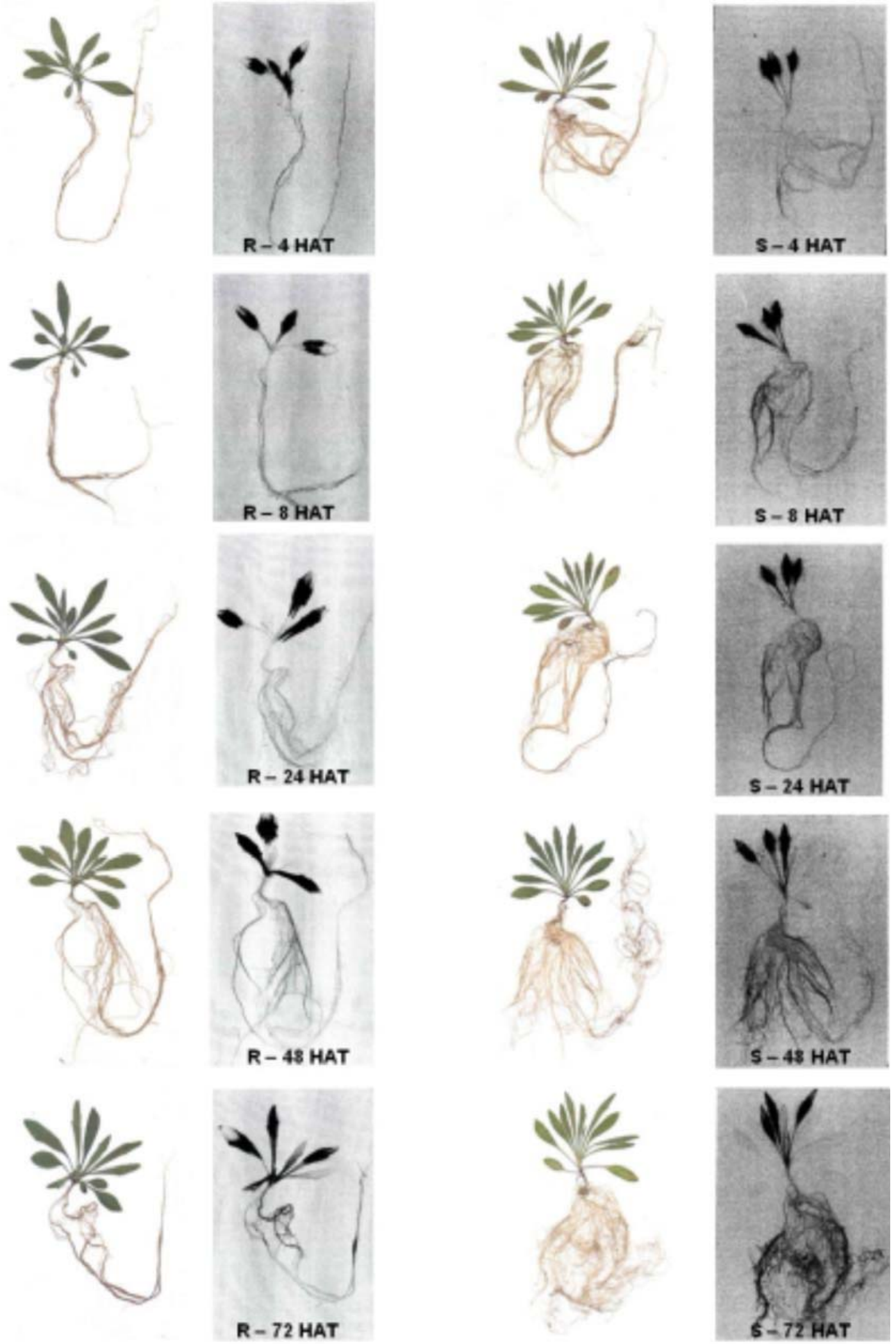

Figure 4 - Translocation autoradiography of ${ }^{14} \mathrm{C}$-glyphosate through $C$. bonariensis glyphosate resistant (R) and glyphosate susceptible (S) vegetal tissues. The darker regions represent the areas of higher radioactivity. 


\section{LITTERATURE CITED}

BAERSON, S. R. et al. Glyphosate-resistant goosegrass. Identification of a mutation in the target enzyme 5enolpyruvylshikimate-3-phophate synthase. Plant Physiol., v. 129, n. 3, p. 1265-1275, 2002.

BECKIE, H. J. et al. Screening for herbicide resistance in weeds. Weed Technol., v. 14, n. 1, p. 428-445, 2000.

BHOWMIK, P. C.; BEKECH, M. M. Horseweed (Conyzacanadensis) seed production, emergence and distribution in no-tillage and conventional-tillage corn (Zea mays). Agronomy, v. 1, n. 1, p. 67-71, 1993.

BRESNAHAN, G. A. et al. Glyphosate applied preharvest induces shikimic acid accumulation in hard red spring wheat (Triticum aestivum). J. Agric. Food Chem., v. 51, n. 14, p. 4004-4007, 2003.

BUHLER, D. D.; OWEN, M. D. K. Emergence and survival of horseweed (Conyza canadensis), Weed Sci., v. 45, n. 1, p. 98-101, 1997.

CHIANG, Y. J.; CHIANG, M. Y. Analysis of shikimate accumulation for diagnosis of glyphosate injury to crops. Plant Protec. B., v. 48, n. 3, p. 243-252, 2006.

CHRISTOFFOLETI, P. J. et al. Glyphosate sustainability in South American cropping systems. Pest Manag. Sci., v. 64, n. 4, p. 422-427, 2008.

CROMARTIE, T. H.; POLGE, N. D. An improved assay for shikimic acid and its use as a monitor for the activity of sulfosate. Proc. Weed Sci. Soc. Am., v. 40, p. 291, 2000.

DINELLI, G. et al. Physiological and molecular insight on the mechanisms of resistance to glyphosate in Conyza canadensis (L.) Cronq. Biotypes. Pestic. Biochem. Physiol., v. 86, n. 1, p. 30-41, 2006.

FENG, P. C. C. et al. Investigations into glyphosate-resistant horseweed (Conyza canadensis): retention, uptake, translocation and metabolism. Weed Sci., v. 52, n. 4, p. 498505, 2004.

FERREIRA, E. A. et al. Distribuição de glyphosate e acúmulo de nutrientes em biótipos de azevém. Planta Daninha, v. 26, n. 1, p. 165-173, 2008.

HEAP, I. The international survey of herbicide resistant weeds. Available in: <www.weedscience.com $>$. Accessed in: April 30, 2008.

KISSMANN, K. G.; GROTH, D. Plantas infestantes e nocivas. Tomo II: Plantas superiores e dicotiledôneas. 2.ed. São Bernardo do Campo: BASF, 1997. 978 p.
KLEIER, D. A.; HSU, F. C. Phloem mobility of xenobiotics. VII the design of phloem systemic pesticides, Weed Sci., v. 44, n. 3, p. 749-756, 1996.

KOGER, C. H.; REDDY, K. N. Role of absorption and translocation in the mechanism of glyphosate resistance in horseweed (Conyza canadensis). Weed Sci., v. 53, n. 1, p. 84-89, 2005.

LORRAINE-COLWILL, D. F. et al. Resistance to glyphosate in Lolium rigidum. Pestic. Sci., v. 55, n. 4, p. 489-491, 1999.

LORRAINE-COLWILL, D. F. et al. Investigations into the mechanism of glyphosate resistance in Lolium rigidum. Pestic. Biochem. Physiol., v. 74, n. 1, p. 62-72, 2003.

MONQUERO, P. A. et al. Absorção, translocação e metabolismo do glyphosate por plantas tolerantes e suscetíveis a este herbicida. Planta Daninha, v. 22, n. 3, p. 445-451, 2004.

MOREIRA, M. S. et al. Resistência de buva (Conyza canadensis e $C$. bonariensis) ao herbicida glyphosate. Planta Daninha, v. 25, n. 1, p. 157-164, 2007.

MOREIRA, M. S.; CHRISTOFFOLETI, P. J. Resistência de plantas daninhas aos herbicidas inibidores da EPSPS (Grupo G). In: CHRISTOFFOLETI, P. J. (Coord.). Aspectos de resistência de plantas daninhas a herbicidas. 3.ed. Campinas: Associação Brasileira de Ação a resistência de Plantas aos Herbicidas (HRAC-BR), 2008. p. 78-96,

MUELLER, T. C. et al. Shikimate Accumulates in Both Glyphosate-Sensitive and Glyphosate-Resistant Horseweed (Conyza canadensis L. Cronq.). J. Agric. Food Chem., v. 51, n. 3, p. 680-684, 2003.

$\mathrm{NG}, \mathrm{C}$. H. et al. Inheritance of glyphosate resistance in goosegrass (Eleusine indica). Weed Sci., v. 54, n. 4, p. 564-570, 2004.

PEDERSEN, B. P. et al. Ecological fitness of a glyphosate resistant Lolium rigidum population: growth and seed production along a competition gradient. Basic Appl. Ecol., v. 8, n. 1, p. 258-268, 2007.

PETERSON, C. A. Physicochemical factors governing the transport of xenobiotic chemicals in plants: movement into roots and partitioning between xylem and phloem,

Acta Hortic., v. 239, n. 1, p. 43-54, 1989.

PRESTON, C.; WAKELIN, A. M. Resistance to glyphosate from altered herbicide translocation pattern. Pest Manag. Sci., v. 64, n. 4, p. 372-376, 2008.

RODRIGUES, B. N.; ALMEIDA, F. S. Guia de herbicidas. 5.ed. Londrina: 2005. 592 p.

Planta Daninha, Viçosa-MG, v. 33, n. 1, p. 109-118, 2015 
STUBBENDIECK, J.; FRIISOE, G. Y.; BOLICK, M. R. Weeds of Nebraska and the great plains. Lincoln: Nebraska Department of Agriculture, 1994. p. $122-123$.

VARGAS, L. et al. Buva (Conyza bonariensis) resistente ao glyphosate na região sul do Brasil. Planta Daninha, v. 25, n. 3, p. 573-578, 2007.
VIDAL, R. A. et al. Impacto da temperatura, irradiância e profundidade das sementes na emergência e germinação de Conyza bonariensis e Conyza canadensis resistentes ao glyphosate. Planta Daninha, v. 25, n. 2, p. 309-315, 2007.

WEAVER, S. E. et al. The biology of Canadian weeds, Conyza canadensis. Canadian J. Plant Sci., v. 81, n. 1, p. 867-875, 2001. 